\title{
Use of chromium picolinate and biotin in the management of type 2 diabetes: an economic analysis
}

\author{
Joseph P. Fuhr Jr. \\ Widener University \\ Hope He \\ Thomas Jefferson University \\ Neil Goldfarb \\ Thomas Jefferson University \\ David B. Nash \\ Thomas Jefferson University
}

Follow this and additional works at: https://jdc.jefferson.edu/healthpolicyfaculty

Part of the Health Services Research Commons

Let us know how access to this document benefits you

\section{Recommended Citation}

Fuhr, Joseph P. Jr.; He, Hope; Goldfarb, Neil; and Nash, David B., "Use of chromium picolinate and biotin in the management of type 2 diabetes: an economic analysis" (2005). College of Population Health Faculty Papers. Paper 25.

https://jdc.jefferson.edu/healthpolicyfaculty/25

This Article is brought to you for free and open access by the Jefferson Digital Commons. The Jefferson Digital Commons is a service of Thomas Jefferson University's Center for Teaching and Learning (CTL). The Commons is a showcase for Jefferson books and journals, peer-reviewed scholarly publications, unique historical collections from the University archives, and teaching tools. The Jefferson Digital Commons allows researchers and interested readers anywhere in the world to learn about and keep up to date with Jefferson scholarship. This article has been accepted for inclusion in College of Population Health Faculty Papers by an authorized administrator of the Jefferson Digital Commons. For more information, please contact: JeffersonDigitalCommons@jefferson.edu. 


\title{
Use of Chromium Picolinate and Biotin in the Management of Type 2 Diabetes: An Economic Analysis
}

\author{
JOSEPH P. FUHR, Jr., Ph.D., ${ }^{1,2}$ HOPE HE, M.A. M.P.A., ${ }^{2}$ NEIL GOLDFARB, B.A., ${ }^{2}$ \\ and DAVID B. NASH, M.D., M.B.A. ${ }^{2}$
}

\begin{abstract}
This paper addresses the potential economic benefits of chromium picolinate plus biotin (Diachrome $^{\circledR}$ ) use in people with Type 2 diabetes (T2DM). The economic model was developed to estimate the impact on health care systems' costs by improved $\mathrm{HbA}_{1 \mathrm{C}}$ levels with chromium picolinate plus biotin (Diachrome). Lifetimes cost savings were estimated by adjusting a benchmark from the literature, using a price index to adjust for inflation. The cost of diabetes is highly dependent on the $\mathrm{HbA}_{1 \mathrm{C}}$ level with higher initial levels and higher annual increments increasing the cost. Improvement in glycemic control has proven to be cost-effective in delaying the onset and progression of T2DM, reducing the risk for diabetes-associated complications and lowering utilization and cost of care. Chromium picolinate plus biotin (Diachrome) showed greater improvement of glycemic control in poorly controlled T2DM patients $\left(\mathrm{HbA}_{1 \mathrm{C}} \geq \mathbf{1 0} \%\right)$ compared to their better controlled counterparts $\left(\mathrm{HbA}_{1 \mathrm{C}}<10 \%\right)$. This improvement was additive to that achieved by oral hypoglycemic medications and correlates to calculated levels of cost savings. Average 3-year cost savings for chromium picolinate plus biotin (Diachrome) use could range from $\$ 1,636$ for a poorly controlled patient with diabetes without heart diseases or hypertension, to $\$ 5,435$ for a poorly controlled patient with diabetes, heart disease, and hypertension. Average 3-year cost savings was estimated to be between $\$ 3.9$ billion and $\$ 52.9$ billion for the $\mathbf{1 6 . 3}$ million existing patients with diabetes. Chromium picolinate plus biotin (Diachrome) use among the 1.17 million newly diagnosed patients with T2DM each year could deliver lifetime cost savings of $\$ 42$ billion, or $\$ 36,000$ per T2DM patient. Affordable, safe, and convenient, chromium picolinate plus biotin (Diachrome) could prove to be a cost-effective complement to existing pharmacological therapies for controlling T2DM. (Disease Management 2005;8:265-275)
\end{abstract}

\section{INTRODUCTION}

D IABETES is a serious, costly metabolism disorder affecting $6.3 \%$ of the US population, or approximately 18.2 million people. ${ }^{1}$ Type 2 diabetes (T2DM) accounts for $90 \%-95 \%$ of all di- abetes and affects more than 16.3 million adult Americans, incurring substantial economic burden to the individual and the society. ${ }^{2}$ The risk and prevalence of T2DM increases steadily with age, and nearly half of all people with T2DM are older than 65 years. ${ }^{1,3}$ By age 60, approximately

${ }^{1}$ Widener University, Department of Economics, Chester, Pennsylvania.

${ }^{2}$ Department of Health Policy, Thomas Jefferson University, Philadelphia, Pennsylvania. 
$10 \%$ of the population is estimated to have T2DM. ${ }^{3}$ Moreover, approximately $9 \%$ of patients with T2DM develop microvascular disease, and $20 \%$ have a macrovascular complication within 9 years of diagnosis. ${ }^{4}$

T2DM is characterized by insulin deficiency, insulin resistance, and impaired insulin secretion. Insulin resistance and abnormally elevated blood sugar levels are its first signs and the underlying causes of the diabetes-associated complications. ${ }^{5,6}$ The risk of diabetes rises relative to the degree of insulin resistance. ${ }^{6}$ As a result, many T2DM medications such as sulfonylureas, non-sulfonylurea secretagogues, biguanides (eg, metformin), and the carbohydrate blockers (acarbose and miglitol) directly target insulin resistance by increasing insulin production in the pancreas, or by decreasing glucose output through the liver, while the insulin-sensitizing tiazolidinediones (TZDs) target different key organs to decrease insulin resistance and improve blood glucose uptake into the cells. ${ }^{7,8}$ Some nonprescription agents (nutritional supplements), such as the essential nutrient chromium, improve insulin sensitivity, while other nutrients, such as biotin, help to improve liver and pancreatic function. ${ }^{9}$ The nutrient combination of chromium picolinate plus biotin (as Diachrome) affects both glucose and lipid pathways and has shown benefits such as improving insulin sensitivity by increasing the number of cellular insulin receptors and activating these receptors, improving glucokinase activity in the liver, and improving pancreatic $\beta$-islet cell function. ${ }^{10}$

The treatment goal for T2DM essentially is to improve glycemic control and to adapt to medical regimens and lifestyle changes, which has proved cost-effective. ${ }^{11-13}$ Good glycemic control has proved to be cost-effective in delaying the onset and progression of the disease, reducing the risk for complications, and thus lowering medical utilization and costs of care. ${ }^{14-16}$ Glycosylated hemoglobin $\left(\mathrm{HbA}_{1 \mathrm{C}}\right)$ is the accepted standard measure of glycemic control, while fasting plasma glucose (FPG) indicates immediate diagnosis of diabetes. Individuals with T2DM are more prone to cardiovascular disease (CVD) risk; hence, they also must closely monitor cardiovascular risk factors. The high incidence of CVD among people with T2DM further increases medical utilization and costs of care for these individuals. $4,17,19,72$

The UKPDS (United Kingdom Prospective Diabetes Study) study ${ }^{17}$ results indicated "that for every percentage point decrease in $\mathrm{HbA}_{1 \mathrm{C}}$ (eg, from $9 \%$ to $8 \%$ ), there was a $25 \%$ reduction in diabetes-related deaths, a $7 \%$ reduction in all-cause mortality, and an 18\% reduction in combined fatal and nonfatal myocardial infarction." 18 However, the cost of improving glycemic control can be substantial. For example, in the 1997 UKPDS study, ${ }^{19}$ the costs of intensive and control therapy were $\$ 8,020$ and $\$ 6,740$, respectively. The annual cost in the 1993 Diabetes Control and Complications Trial (DCCT) study ${ }^{19}$ was $\$ 4,000$ for Multiple Daily Injections (MDI), $\$ 5,800$ for Continuous Subcutaneous Insulin Injections (CSII), and \$1,700 for conventional therapy.

Pharmacological therapy has been effective in glucose control and usually is initiated when other methods, such as diet and exercise, fail to manage blood glucose levels within target ranges. The UKPDS study showed that the rigorous treatment of diabetes using blood glucose-lowering agents can decrease the morbidity and mortality of T2DM. Patients who use blood glucose-lowering agents have shown fewer physical symptoms and enhanced well being, ${ }^{12}$ and have had a significantly reduced risk of cardiovascular and microvascular complications. ${ }^{17,20}$ Available oral hypoglycemic agents such as sulphonylureas, non-sulfonylurea secretagogues, metformin, thiazolidinediones, and acarbose have glucose-lowering efficacy $^{21}$ but enhance adverse side effects and other complications related to CVD. These agents have been clinically shown to reduce $\mathrm{HbA}_{1 \mathrm{C}}$ levels an average of $0.5 \%-2.0 \%$. Some of the adverse side effects are gastrointestinal distress, edema, weight gain, hypoglycemic episodes, hepatoxicity, and congestive heart failure (Table 1). These adverse effects can lead to patient intolerance and cessation of therapy, resulting in poor glycemic control and substantial costs. ${ }^{8,21,19}$ As a result, pharmacological treatments are not considered the most costeffective and safe measures for managing T2DM, and helping prevent those at high risk for developing T2DM. ${ }^{2,10}$ 


\begin{tabular}{|c|c|c|c|}
\hline Class & Oral agent & $\begin{array}{l}\text { Average } \\
\text { HbA1c } \\
\text { reduction }\end{array}$ & Common side effects \\
\hline Sulfonylureas & $\begin{array}{l}\text { Glipizide (Glucotrol, Metaglip), } \\
\text { glipizide extended release } \\
\text { (Glucotrol XL), glyburide } \\
\text { (Diabeta), micronized glyburide } \\
\text { (Glucovance), glimepiride } \\
\text { (Amaryl), chlorpropamide } \\
\text { (Diabinese), tolbutamide, } \\
\text { tolazamide }\end{array}$ & $0.8 \%-2.0 \%$ & $\begin{array}{l}\text { Weight gain, } \\
\text { hypoglycemia }\end{array}$ \\
\hline $\begin{array}{l}\text { Non-sulfonylurea } \\
\text { secretagogues }\end{array}$ & $\begin{array}{l}\text { Meglitinides-repaglinide } \\
\text { (Prandin); nateglinide (Starlix) }\end{array}$ & $0.5 \%-2.0 \%$ & $\begin{array}{l}\text { Weight gain, } \\
\text { hypoglycemia }\end{array}$ \\
\hline $\begin{array}{l}\alpha \text {-Glucosidase } \\
\text { inhibitors }\end{array}$ & $\begin{array}{l}\text { Acarbose (Precose), miglitol } \\
\text { (Glyset) }\end{array}$ & $0.7 \%-1.0 \%$ & $\begin{array}{l}\text { Flatulence, abdominal } \\
\text { pain, diarrhea }\end{array}$ \\
\hline Biguanides & $\begin{array}{l}\text { Metformin (Avandamet, Fortamet, } \\
\text { Glucophage), metformin extended } \\
\text { release (Glucophage XR) }\end{array}$ & $1.5 \%-2.0 \%$ & $\begin{array}{l}\text { Diarrhea, flatulence, } \\
\text { nausea and vomiting, } \\
\text { abdominal pain, lactic } \\
\text { acidosis, vitamin B12 } \\
\text { malabsorption }\end{array}$ \\
\hline $\begin{array}{l}\text { Thiazolidinediones } \\
\text { (TZDs) }\end{array}$ & $\begin{array}{l}\text { Rosiglitazone (Avandia), } \\
\text { pioglitazone (Actos) }\end{array}$ & $0.5 \%-1.5 \%$ & $\begin{array}{l}\text { Congestive heart } \\
\text { failure, hepatoxicity, } \\
\text { peripheral edema, } \\
\text { anemia, weight gain }\end{array}$ \\
\hline $\begin{array}{l}\text { Nutritional } \\
\text { supplement }\end{array}$ & $\begin{array}{l}\text { Chromium picolinate and biotin } \\
\text { (Diachrome) }\end{array}$ & $0.5 \%-1.94 \%$ & None \\
\hline
\end{tabular}

As the disease progresses, to maintain the optimum $\mathrm{HbA}_{1 \mathrm{C}}$ levels, it is often necessary and cost-effective to treat the patient not only with more than one pharmacological agent (including using insulin), but also to complement the pharmacological treatments with other adjunctive therapies such as nutritional measures. ${ }^{22}$ Chromium picolinate, when administered in combination with biotin (Diachrome), has shown to be a cost-effective, safe adjunctive treatment. ${ }^{23}$ Like other nutritional therapies for patients with T2DM, chromium picolinate plus biotin (Diachrome) is aimed at helping patients achieve glycemic control, improve serum lipids, and ultimately reduce risk of associated complications. ${ }^{24}$

\section{Economic and health impact of glycemic control}

The economic burden of diabetes alone has grown to $\$ 132$ billion in 2002, including direct medical expenditures and the costs of foregone productivity.,25 From 1997 to 2002, the per capita costs of diabetes rose $30 \% .{ }^{1,25}$ The majority of these costs can be attributed to various diabetes-associated complications, such as CVD, which accounts for $52 \%$ of costs. ${ }^{26-31}$ One study showed patients with diabetes cost an excess of $\$ 3,494$ per person, which was 2.4 times more for diabetic members than for matched control subjects. In addition, $37.6 \%$ of total direct excess costs per patient per year were attributable to long-term complications, and an additional $4 \%$ were due to short-term complications. ${ }^{26}$ Moreover, the average direct cost of managing complications over 30 years was shown to be $\$ 47,240$ per patient for those who had been treated for 5 years and with a mean $\mathrm{HbA}_{1 \mathrm{C}}$ of 8.4 , assuming $\mathrm{HbA}_{1 \mathrm{C}}$ would increase by 0.15 percentage points annually, other things being equal. ${ }^{32}$

Furthermore, the economic burden from impending diabetes is apparent at least 8 years before diagnosis, with the average diabetes-associated incremental direct cost of $\$ 1,205$ per type 2 diabetic patient per year during the first 8 prediagnostic years. ${ }^{31}$ A related study found that the average incremental cost of diabetes was $\$ 2,257$ per year during the first 8 postdiagnostic years. ${ }^{30}$ In addition, the cost of dia- 
betes is highly dependent on the level of $\mathrm{HbA}_{1 \mathrm{C}}$. Higher initial levels will increase the cost as will higher increments per year. ${ }^{32} \mathrm{Im}$ provement in glycemic control has proven to be cost-effective in delaying the onset and progression of T2DM, reducing the risk for complications associated with diabetes, and lowering utilization and cost of care. ${ }^{17,19,24,29,34,41} \mathrm{~A}$ decrease of $\mathrm{HbA}_{1 \mathrm{C}}$ levels of 1.0 percentage point could decrease significantly the cost of healthcare. ${ }^{36}$

\section{Economic analysis}

In a study by Gilmer et al, ${ }^{35}$ medical care charges increase for every one percentage point increase in $\mathrm{HbA}_{1 \mathrm{C}}$ above $7 \%$. So, for an individual with an $\mathrm{HbA}_{1 \mathrm{C}}$ value of $6 \%$, successive increases of one percentage point in $\mathrm{HbA}_{1 \mathrm{C}}$ will result in cumulative increases in charges of approximately $4 \%, 10 \%, 20 \%$, and $30 \%$, respectively. In another study, using general linear regression, Gilmer et $\mathrm{al}^{37}$ estimated the relationship between 3-year health care costs and baseline $\mathrm{HbA}_{1 \mathrm{C}}$ levels as well as other independent variables. The results demonstrated that a decrease in $\mathrm{HbA}_{1 \mathrm{C}}$ from $10 \%$ to $9 \%$ could result in a direct cost savings of $\$ 805$ over a 3year period for patients with diabetes without heart diseases or hypertension, $\$ 1,130$ for patients with diabetes and hypertension, \$2,078 for patients with diabetes and heart disease, and \$2675 for patients with diabetes, heart disease, and hypertension.

Ginsberg et $\mathrm{al}^{38}$ examines the effect of a disease state management system that emphasizes a care system for diabetics, primary care providers, and a team approach. No control group is involved, and the approach is one of treatment goals and time lines being set for success with individual therapies. The study estimated that a reduction in $\mathrm{HbA}_{1 \mathrm{C}}$ from $9.2 \%$ to $7.4 \%$ would result in a net direct lifetime cost savings of $\$ 27,000$ after payment for the disease management program. The cost of the diabetes management program was approximately $\$ 800$ annually.

In a retrospective study using regression analysis, Menzin et al ${ }^{39}$ examined the potential short-term economic benefits of improved glycemic control on selected short-term complications of diabetes. Patients improving from fair
( $8 \%$ to $10 \%$ ) to good control (less than $8 \%$ ) had a reduction in healthcare charges of $\$ 410$, poor (greater than $10 \%$ ) to fair had a $\$ 1,660$ reduction, and poor to good had a $\$ 2,070$ reduction in health care charges over the same 3-year period. The adjusted admissions per 100 were 30, 38 , and 74 , and the mean adjusted charges were $\$ 2,610, \$ 3,810$, and $\$ 8,320$ over the 3-year period.

In comparing patients with different levels of $\mathrm{HbA}_{1} \mathrm{C}$, Wagner ${ }^{40}$ has shown that "a sustained reduction in $\mathrm{HbA}_{1 \mathrm{C}}$ level among diabetic patients is associated with a significant cost savings within 1-2 years of improvement." Wagner used multiple linear regression analysis to estimate the relationship between glycemic control and cost of patients. In his study, he compared the health utilization and costs between one group of diabetic patients with a one percentage point lowering of $\mathrm{HbA}_{1 \mathrm{C}}$ and another group with no $\mathrm{HbA}_{1 \mathrm{C}}$ improvement. The total cost in the first year was lower but not significantly lower. In years $2-4$, the cost savings for the improved cohort were significantly lower, and during the last 3 years of the study the average cost savings ranged between $\$ 685$ and $\$ 950$ per patient per year.

Another paper analyzes the cost savings from a medical perspective. Testa and Simonson $^{41}$ examined the gains from a societal perspective. Patients were randomized and given either a placebo or glipizide GITS. Both groups also were put on diet management. The study was for 12 weeks with the cohort receiving the treatment experiencing less absenteeism for a gain of $\$ 91$ per month, fewer days confined to bed for a gain of $\$ 304$ per 1000 person-days, and fewer restricted-activity days with a gain of $\$ 2,615$ per 1000 person-days. There was no mention of the cost of the program.

\section{Diachrome and its effects on glycemic control}

Chromium III, the most stable and nutritional form of chromium, is a safe trace element essential for normal carbohydrate and lipid metabolism and potentiates insulin. ${ }^{42-44}$ Chromium III has long been shown to improve insulin sensitivity, enhance glucokinase activity, and lower blood glucose levels in people with insulin resistance and T2DM in both randomized ${ }^{48-57}$ and open-label studies. ${ }^{44,45}$ Chromium picolinate is 
absorbable, safe, and the most widely tested form of Chromium III. ${ }^{42-68}$ Biotin is a water-soluble B vitamin known to play a role in glucose metabolism by helping to break down glucose as well as enhance insulin sensitivity. Biotin stimulates the activity of glucokinase in the liver and improves pancreatic $\beta$-islet cell function. ${ }^{69} \mathrm{Di}$ achrome is the formulation of $600 \mathrm{mcg}$ of chromium (as chromium picolinate) plus $2 \mathrm{mg}$ of biotin. The supplementation effects of the combination of chromium picolinate plus biotin were first proposed in the mid-1990s by researchers at Nutrition 21 , Inc. ${ }^{10}$ Cell culture studies confirmed a synergistic effect of the combination on glucose uptake and glycogen synthesis in skeletal muscle cell cultures. ${ }^{67}$ Animal models confirmed these results and further identified an improvement on lipid profiles, particularly reductions in total cholesterol and increases in HDL-cholesterol in obese, hyperinsulinemic rats. ${ }^{70}$ Clinical research, including both open-la$\mathrm{bel}^{72}$ and randomized, double-blind, placebocontrolled, multicenter trials, ${ }^{71}$ verified the significant effect of chromium picolinate plus biotin (Diachrome) on both glycemic control and lipid profiles in patients with T2DM when used as adjunctive nutrition therapy to prescription oral antidiabetic agents. This combination appears to combat insulin resistance, to improve beta cell function, to enhance postprandial glucose uptake, and to inhibit excessive hepatic glucose production through increasing glycogen syntheses levels in human skeletal muscle culture. ${ }^{73-77}$ As a result, chromium picolinate plus biotin (Diachrome), when used with standard treatments, can significantly improve blood sugar control for people with and at high risk for T2DM. ${ }^{45,78}$ In addition, in a 12-week randomized, doubleblind, placebo-controlled, multicenter study of 453 patients with T2DM, ${ }^{79}$ chromium picolinate plus biotin (Diachrome) decreased the mean $\mathrm{HbA}_{1 \mathrm{C}}$ level by 0.51 (from 8.71 to 8.20 ) percentage points for patients with T2DM who had been taking oral antihyperglycemic drugs for at least the past 6 months. The more poorly controlled patients (based on baseline $\mathrm{HbA}_{1 \mathrm{C}}$ levels) achieved the greatest improvements in their glycemic control by the end of the study. For patients who had baseline $\mathrm{HbA}_{1 \mathrm{C}}$ levels of at least $10 \%$, the mean $\mathrm{HbA}_{1 \mathrm{C}}$ levels decreased by 1.78 (from 11.07 to 9.29) percentage points, whereas for those who had baseline levels of at least $11 \%$, the mean $\mathrm{HbA}_{1 \mathrm{C}}$ levels decreased by 1.96 (from 11.86 to 9.90 ) percentage points (Fig. 1).

The only difference pre- and post-study was the use of chromium picolinate plus biotin (Di-

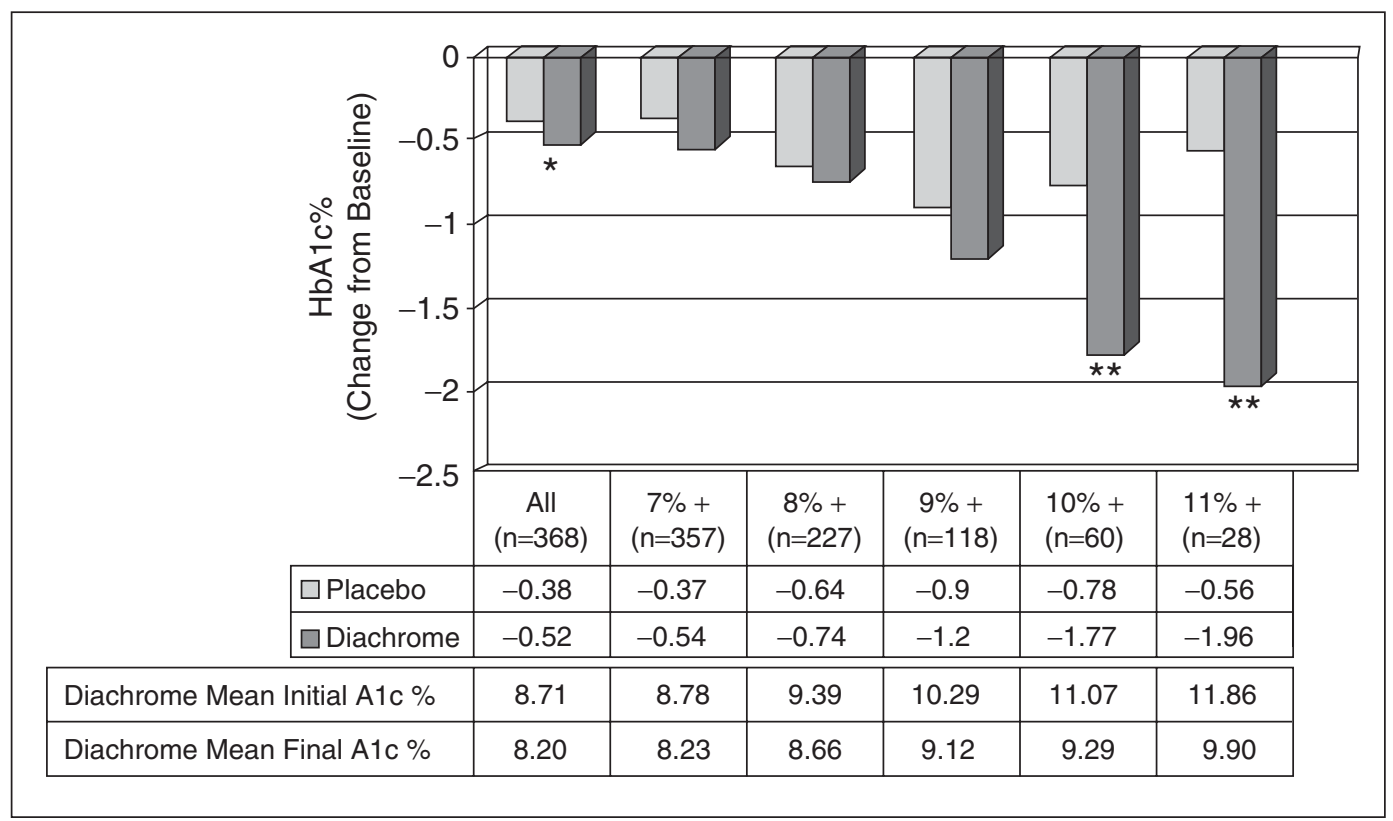

FIG. 1. Diachrome study results. Effect on HbA1c levels. All, data from all subjects with baseline and final visits; $\mathrm{n} \%+$, data from subjects with baseline HbA1c levels $\geq \mathrm{n} \%$; ${ }^{*}$, sig. diff. $(p<0.01)$ using ANCOVA (treatment ${ }^{*}$ baseline $\mathrm{HbA} 1 \mathrm{c}) ;{ }^{* *}$, sig. diff. $(p<0.02)$ compared to placebo. 
achrome). ${ }^{80}$ Two randomized, double-blind, placebo-controlled multicenter prospective studies further confirm the findings of improved glycemic control and lipid profiles in T2DM from this large prospective trial. ${ }^{79,81,82}$ Chromium picolinate plus biotin (Diachrome) was studied as adjunctive nutritional therapy in patients with T2DM. The resulting improvement in glycemic control observed in each of these clinical trials was beyond that already achieved by use of the oral hypoglycemic medications. The purpose of this study is to estimate the potential cost savings that result from the decrease in $\mathrm{HbA}_{1 \mathrm{C}}$ through the use of Diachrome. This paper addresses the potential economic benefits of chromium picolinate plus biotin (Diachrome ${ }^{\circledR}$ ) use in people with T2DM.

\section{METHODS AND RESULTS}

A 12-week clinical study showed that the use of Diachrome significantly decreased the average $\mathrm{HbA}_{1 \mathrm{C}}$ at all levels of initial $\mathrm{HbA}_{1 \mathrm{C}}(p<$ $0.05)$. For example, for all patients in this study receiving Diachrome the mean $\mathrm{HbA}_{1 \mathrm{C}}$ decreased by 0.51 from 8.71 to 8.20 , and the $95 \%$ confidence interval for the group after the study was $8.20 \pm 0.16$ (Fig. 1).

At all baseline levels Diachrome outperformed the placebo. However, only at levels of baseline $\mathrm{HbA}_{1 \mathrm{C}}$ of at least $10 \%$ was the difference statistically significant $(p<0.02)$. In patients with baseline levels of at least $10 \%$ $\mathrm{HbA}_{1 \mathrm{C}}$, the average $\mathrm{HbA}_{1 \mathrm{C}}$ level decreased by 1.78 percentage points with Diachrome compared to 0.78 percentage points with the placebo (Fig. 1). The baseline average $\mathrm{HbA}_{1 \mathrm{C}}$ in the Diachrome group was $11.07 \%$ whereas after the study the average $\mathrm{HbA}_{1 \mathrm{C}}$ was 9.29 with a $95 \%$ confidence interval of $9.29 \pm 0.53$.

Chromium picolinate plus biotin (Diachrome) is a relatively low-cost adjunct method of controlling $\mathrm{HbA}_{1 \mathrm{C}}$ for $\mathrm{T} 2 \mathrm{DM}$. The introductory cost of the recommended tablet per day is $\$ 19.95$ per 60-count bottle, and the annual cost would be less than $\$ 120$, which is considerably less than the cost of intensive and control therapies that have been examined in other studies. The potential clinical and economic benefits, therefore, could be considerable. Based on the literature re- view and research findings, we constructed various estimates of the potential benefits of the use of chromium picolinate plus biotin (Diachrome) in T2DM.

The economic model employed to estimate the potential economic benefit from the use of chromium picolinate plus biotin (Diachrome) began with the establishment of a benchmark value for the direct cost savings reported in the literature for decreases in the level of $\mathrm{HbA}_{1 \mathrm{C}}$. The benchmark was then adjusted for inflation using the Medical Care Service Inflation Index which is a component of the Consumer Price Index. In some cases extrapolation was utilized so that the data found in the literature would conform to the study results. Statistical analysis was used to estimate a range of potential 3year cost savings. Lifetime cost savings were estimated by adjusting a benchmark from the literature, and using the same price index to adjust for inflation.

Wagner et $\mathrm{al}^{14}$ estimated an average annual cost savings per patient of \$685-\$950. These prices were adjusted to 2004 levels by using the January value of each year's Medical Care Services Inflation Index, a component of the Consumer Price Index. The result was an average annual cost savings of $\$ 978-\$ 1,300$.

The Gilmer ${ }^{37}$ data was extrapolated to reflect the changes in average $\mathrm{HbA}_{1 \mathrm{C}}$ from $10.62 \%$ to $9.18 \%$. Using the data in Gilmer's study and adjusting the Medical Care Service Index to 2004 with 2002 as the base year, the average 3-year cost savings range from $\$ 1,636$ for patients with diabetes only, to $\$ 5,435$ for a patient with diabetes, heart disease, and hypertension (Table 2).

In addition, the retrospective study of Menzin et $\mathrm{al}^{39}$ showed that depending on the change in health category (poor, fair, good), the

\begin{tabular}{|c|c|}
\hline \multicolumn{2}{|c|}{$\begin{array}{c}\text { Table 2. Changes in HbA } \mathrm{H}_{1 \mathrm{c}} \text { LeVels: } \\
\text { Three-YeAr Cost SAVIngs }\end{array}$} \\
\hline Patient classification & $11.07 \%-9.29 \%$ \\
\hline $\begin{array}{l}\text { Diabetes with heart disease/ } \\
\text { hypertension }\end{array}$ & $\$ 5,435$ \\
\hline Diabetes with heart disease & $\$ 4,221$ \\
\hline Diabetes with hypertension & $\$ 2,296$ \\
\hline $\begin{array}{l}\text { Diabetes without heart diseases } \\
\text { or hypertension }\end{array}$ & $\$ 1,636$ \\
\hline Overall & $\$ 2,791$ \\
\hline
\end{tabular}


reduction in health care cost would range from $\$ 410$ to $\$ 2,070$ over a 3-year period. Adjusting for inflation to 2004 dollars the respective health care cost reduction over 3 years would be $\$ 562-\$ 2,836$.

\section{Existing T2DM patient savings estimate}

The medical cost savings from decreasing $\mathrm{HbA}_{1 \mathrm{C}}$ levels varies among different studies depending on the assumptions made, such as severity of illness and initial level of $\mathrm{HbA}_{1 \mathrm{C}}$. As a result, the average medical cost savings per diabetic are difficult to ascertain. However, under all scenarios the annual medical cost savings is greater than the $\$ 120$ annual cost of chromium picolinate plus biotin (Diachrome). The Menzin study showed the average annual cost savings to be between $\$ 978$ and $\$ 1300$ for those whose $\mathrm{HbA}_{1 \mathrm{C}}$ decreased by more than one percentage point. Using sensitivity analysis, three different estimates of annual medical cost savings of $\$ 200, \$ 500$, and $\$ 1,000$ are assumed. The annual potential cost savings of using chromium picolinate plus biotin (Diachrome) are $\$ 80(\$ 200-\$ 120), \$ 380$, and $\$ 880$, respectively. If the approximately 16.3 million type 2 diabetics $(18.1 \mathrm{M} \times 0.9)$ used chromium picolinate plus biotin (Diachrome), the estimated 3-year cost savings would be $\$ 3.9$ billion, $\$ 18.6$ billion, or $\$ 52.9$ billion, respectively (Table 3). Adding the pain and suffering associated with the additional medical complications, the time cost, and lost productivity, the savings from the use of chromium picolinate plus biotin (Diachrome) could be substantial.

Newly diagnosed T2DM patient savings estimate

About 1.3 million people are diagnosed each year with diabetes, approximately $90 \%$ of whom have T2DM. Using Ginsberg's estimated lifetime cost savings of $\$ 27,000$ ( $\$ 36,000$ in 2004 dollars) per patient with good diabetes control, just for the newly diagnosed population with T2DM in 2004, the health care system could achieve lifetime cost savings of approximately $\$ 42$ billion. Adding chromium picolinate plus biotin (Diachrome) to this regimen appears to be economically judicious for both newly diagnosed patients as well as existing patients with T2DM, based upon the significant potential annual and lifetime cost savings.

\section{DISCUSSION}

Controlling diabetes in its early stages is necessary, and the progression of the disease is very expensive. A low-cost intervention could be beneficial to patients, third party payers, and society as a whole. Nutrition research is elucidating the important role that certain safe, inexpensive, essential nutrients may play in disease prevention and progression by reducing major risk factors in T2DM. Chromium and biotin are two such affordable essential nutrients that each have been clinically shown to be safe and effective in improving glycemic control in T2DM by enhancing insulin sensitivity and improving glucose metabolism. Research conducted at the United States Department of Agriculture (USDA) reported an improvement in glycemic control in T2DM subjects taking chromium picolinate as adjunct nutrition therapy to oral hypoglycemic medications. ${ }^{60}$ Ravina et $\mathrm{al}^{45}$ reported on the improvement in glycemic control in subjects with steroid-induced diabetes who took chromium picolinate. In another study, Ravina et $\mathrm{al}^{86}$ reported on improved glycemic control in patients with type 1 diabetes who added chromium picolinate to their treatment regimen and reduced their in-

\begin{tabular}{|lccccc|}
\hline & Table 3. & Type 2 Diabetes Population-Wide Three-Year Cost Savings & \\
\hline & $\begin{array}{c}\text { Annual cost } \\
\text { savings per } \\
\text { patient }\end{array}$ & $\begin{array}{c}\text { Annual cost } \\
\text { of diachrome } \\
\text { per patient }\end{array}$ & $\begin{array}{c}\text { Net benefit of } \\
\text { use of diachrome } \\
\text { per patient }\end{array}$ & $\begin{array}{c}\text { Annual benefit } \\
\text { of diachrome } \\
\text { use }\end{array}$ & $\begin{array}{c}\text { Three-year } \\
\text { benefit of } \\
\text { diachrome use }\end{array}$ \\
\hline $16.3 \mathrm{M}$ & $\$ 200$ & $\$ 120$ & $\$ 80$ & $\$ 1.3 \mathrm{~B}$ & $\$ 3.9 \mathrm{~B}$ \\
$16.3 \mathrm{M}$ & $\$ 500$ & $\$ 120$ & $\$ 380$ & $\$ 6.2 \mathrm{~B}$ & $\$ 18.6 \mathrm{~B}$ \\
$16.3 \mathrm{M}$ & $\$ 1000$ & $\$ 120$ & $\$ 880$ & $\$ 14.3 \mathrm{~B}$ & $\$ 52.9 \mathrm{~B}$ \\
\hline
\end{tabular}


sulin dosage by 50\%. Researchers at Harvard School of Public Health reported an inverse relationship between tissue chromium status and the incidence of diabetes and cardiovascular disease. ${ }^{83}$ Chromium's effect on glycemic control has been noted in research literature since the early 1950s. ${ }^{84,85}$ Similarly, biotin has an impact on glucose metabolism and insulin sensitivity. ${ }^{87-89}$ Diachrome, a new, low-cost nutritional therapy for T2DM, is a patented formulation of chromium picolinate and biotin.

Recent clinical trials suggest this composition improves insulin sensitivity and has a positive dual effect on both glycemic control and lipid profiles in T2DM. Furthermore, it is well tolerated with no significant adverse effects. A recent controlled study in T2DM demonstrated a significant decrease in average $\mathrm{HbA}_{1 \mathrm{C}}$ levels of 1.78 percentage points in patients with initial levels of at least $9.5 \%$, and 1.96 percentage points in patients with initial levels of at least $11 \%$ over a 12 -week course of therapy, with an increased effect seen in subjects with higher baseline levels. At the final visit, FPG levels were lower in the active than in the placebo group (159 vs. $171 \mathrm{mg} / \mathrm{dL}$ ). Furthermore, in subjects with baseline cholesterol $>200 \mathrm{mg} / \mathrm{dL}$, total cholesterol $(-19.11 \mathrm{vs} .-5.87 \mathrm{mg} / \mathrm{dL})$ and LDL-cholesterol (-21.7 vs. $-8.2 \mathrm{mg} / \mathrm{dL}$ ) were significantly improved in actives compared to the placebo group.

The significant clinical impact of this nonprescription nutritional product on both glycemic control and lipid profiles, coupled with the absence of any product-related adverse events and its low cost, raise the question of the potential pharmacoeconomic value that this product could offer in the management of T2DM. Based on the clinical results, cost savings calculations indicate that its use could yield a $\$ 36,000$ inflation-adjusted lifetime health care cost savings per patient. An average 3-year cost savings was estimated to be between $\$ 3.9$ billion and $\$ 52.9$ billion for the 16.3 million existing patients with diabetes. Diachrome use among the 1.2 million newly diagnosed patients with T2DM each year could deliver lifetime cost savings of $\$ 42$ billion. Affordable, safe, and convenient, chromium picolinate plus biotin (Diachrome) could prove to be a cost-effective complement to existing pharmacological therapies for controlling T2DM.
This economic analysis is based on the reduction in $\mathrm{HbA}_{1 \mathrm{C}}$ in the clinical trial and the data used for estimating cost savings are from the existing literature. Chromium picolinate plus biotin (Diachrome) also has shown significant positive clinical effect on lipid profiles. Additional cost savings can be expected based on this clinical improvement ${ }^{32}$ and it is recommended that economic analyses be conducted to quantify these additional potential cost savings.

\section{CONCLUSION}

Given the chronic nature of the disease and the devastating potential to develop costly complications, it is important to use the most cost-effective measure to help improve glycemic control in people afflicted with and at higher risk for T2DM. Medical nutrition therapy is one option.

Affordable, safe, convenient, and nutritional, chromium picolinate plus biotin (Diachrome) is considered by some "a definitive therapy" for people with T2DM. ${ }^{73}$ It is being advocated as an effective complement to existing therapies for preventing and treating T2DM, with the potential of reducing the cost of care while maintaining quality of care and improving the quality of life for patients with T2DM. Chromium picolinate plus biotin's (Diachrome's) dual effect on both glycemic control and lipid profiles is unique among antidiabetes medications. It has few, if any, negative side effects compared to other therapies. Our study has shown that chromium picolinate plus biotin (Diachrome) is a cost-effective adjunctive therapy in the management of patients with T2DM and can substantially decrease the health care costs related to T2DM.

\section{ACKNOWLEDGMENTS}

This research was supported by a research grant from Nutrition 21, Inc.

\section{REFERENCES}

1. American Diabetes Association (ADA). Clinical practice recommendations 2001. Available at:〈http:// 
www.diabetes.org.diabetescare $\rangle$ Accessed November 26, 2001.

2. American Diabetes Association (ADA). Diabetes facts and figures. Available at: 〈http://www.diabetes.org Accessed 2004.

3. Palmer CF. Special issues in the management of elderly patients with diabetes. Mt Sinai J Med 1991; 58:287-292.

4. Turner RC, Holman RR. The UK Prospective Diabetes Study. UK Prospective Diabetes Study Group. Ann Med 1996;28:439-444.

5. Stoecker BJ. In: Shils ME, Olsen JA, Shike M, Ross AC, eds. Modern nutrition in health and disease. $9^{\text {th }}$ ed. Baltimore, MD: Williams \& Wilkins, 1999:277-282.

6. Resnick HE, Jones K, Ruotolo G, et al. Insulin resistance, the metabolic syndrome, and risk of incident cardiovascular disease in nondiabetic American Indians: The Strong Heart Study. Diabetes Care 2003; 26:861-867.

7. WebMD Type 2 diabetes: recently diagnosed. Medication choices. Available at: 〈http://my.webmd. com/hw/diabetes_1_2/uq1130.asp?pagenumber $=2\rangle$ Accessed December 2004.

8. Diabetes Control Newslett Issue 158, June 4, 2003. Available at: 〈http://www.diabetesincontrol.com/〉 Accessed December 2004.

9. Bonnefont-Rousselot D. The role of antioxidant micronutrients in the prevention of diabetic complications. Treat Endocrinol 2004;3:41-52.

10. McCarty MF. Toward practical prevention of type 2 diabetes. Med Hypotheses 2000;54:786-793.

11. Groop LC. In: DeFronzo RA, ed. Current therapy of diabetes mellitus. St. Louis, MO: Mosby-Year Book, 1998:96-101.

12. Via PS, Salyer J. Psychosocial self-efficacy and personal characteristics of veterans attending a diabetes education program. Diabetes Educ 1999;25:727-737.

13. Funnell MM. The older adult with diabetes. Nurse Pract Forum 1998;9:98-107.

14. Wagner EH, Sandhu N, Newton KM, McCullough DK, Ramsey SD, Grohaus LC. Effect of improved glycemic control on health care costs and utilization. JAMA 2000;285:182-189.

15. Testa MA, Simonson DC. Health economic benefits and quality of life during improved glycemic control in patients with type 2 diabetes: a randomized, controlled clinical trial. JAMA 1998;280:1490-1496.

16. Meier JL, Swislocki AL, Lopez JR, Noth RH, Bartlebaugh P, Siegel D. Reduction in self-monitoring of blood glucose in persons with type 2 diabetes results in cost savings and no change in glycemic control. Am J Manag Care 2002;8:557-565.

17. U.K. Prospective Diabetes Study (UKPDS) Group. Intensive blood-glucose control with sulfonylureas or insulin compared with conventional treatment and risk of complications in patients with type 2 diabetes. Lancet 1998;352:837-885.

18. Genuth S, Eastman R, Kahn R, et al. American Diabetes Association. Implications of the United Kingdom Prospective Diabetes Study. Diabetes Care 2003;26:S28-S32.
19. Diabetes Control and Complications Trial Research Group. The effect of intensive treatment of diabetes on the development and progression of long-term complications in insulin-dependent diabetes mellitus. N Engl J Med 1993;329:977-986.

20. Gaede P, Vedel P, Larsen N, Jensen GV, Parving HH, Pedersen O. Multifactorial intervention and cardiovascular disease in patients with type 2 diabetes. $\underline{N}$ Engl J Med 2003;348:383-393.

21. United Kingdom Prospective Diabetes Study (UKPDS) Group. UKPDS 13: relative efficiency of randomly allocated diet, sulfonylurea, insulin or metformin in patients with newly diagnosed non-insulin dependent diabetes followed for three years. BMJ 1995;310:83-88.

22. Brown M. Harnessing chromium in the fight against diabetes. DDT 2003;8.

23. Adis Editors. Nutritional supplements could produce significant savings. Inpharma 2004;1458:5. Available at: 〈http://www.adis.com Nutritional supplements savings.htm $\rangle$.

24. Neff LM. Evidence-based dietary recommendations for patients with Type 2 diabetes mellitus. Nutr Clin Care 2003;6:51-61.

25. King H, Aubert RE, Herman WH. Global burden of diabetes, 1995-2025: prevalence, numerical estimates, and projections. Diabetes Care 1998;21:1414-1431.

26. Selby JV, Ray GT, Zhang D, Colby CJ. Excess costs of medical care for patients with diabetes in a managed care population. Diabetes Care 1997;20: 1396-1402.

27. Glauber HS, Brown JB. Impact of cardiovascular disease on health care utilization in a defined diabetic population. J Clin Epidemiol 1994;47:1133-1142.

28. Currier CJ, Morgan CL, Peter JR. Patterns and costs of hospital care for coronary heart disease related and not related to diabetes. Heart 1997;78:544-549.

29. O’Brien JA, Shomphe LA, Kavanagh PL, Raggio G, Caro, JJ. Direct medical costs of complications resulting from type 2 diabetes in the U.S. Diabetes Care 1998;21:1122-1128.

30. Brown JB, Nicholas GA, Glauber HS, Bakst AW. Type 2 diabetes: Incremental medical care costs during the first 8 years after diagnosis. Diabetes Care 1999; 22:1116-1124.

31. Nichols GA, Glauber HS, Brown JB. Type 2 diabetes: Incremental medical care costs during the 8 years preceding diagnosis. Diabetes Care 2000;23:1654-1659.

32. Caro JJ, Ward AJ, O’Brien JA. Lifetime costs of complications resulting from type 2 diabetes in the U.S. Diabetes Care 2002;25:476-481.

33. Stratton IM, Adler AI, Neil HA, et al. Association of glycaemia with macrovascular and microvascular complications of type 2 diabetes (UKPDS 35): prospective observational study. BMJ 2000;321: 405-412.

34. Clark CM Jr, Fradkin JE, Hiss RG, Lorenz RA, Vinicor F, Warren-Boulton E. The National Diabetes Education Program, changing the way diabetes is treated: comprehensive diabetes care. Diabetes Care 2001;24:617-618. 
35. Gilmer TP, O'Connor PJ, Manning WG, Rush WA. The cost to health plans of poor glycemic control. Diabetes Care 1997;20:1847-1853.

36. Gray A, Raikou M, McGuire A, et al. Cost effectiveness of an intensive blood glucose control policy in patients with type 2 diabetes: economic analysis alongside randomized controlled trial (UKPDS 41). BMJ 2000;320:1373-1378.

37. Gilmer TP, Whitebird RR, O'Connor PJ, et al. Predictors of health care costs in adults with diabetes. Diabetes Care 2005;28:59-64.

38. Ginsberg BH, Tan M, Mazze R, Bergelson A. Staged diabetes management: computerizing a disease state management program. J Med Syst 1998;22:77-87.

39. Menzin J, Langley-Hawthorne C, Friedman M, Boulanger L, Cavanaugh R. Potential short-term economic benefits of improved glycemic control: a managed care perspective. Diabetes Care 2001;24: 51-55.

40. Wagner EH, Sandhu N, Newtown KM, McCulloch DK, Ramsey SD, Grothaus LC. Effect of improved glycemic control on health care costs and utilization. JAMA 2001;285:182-189.

41. Testa MA, Simonson DC. Health economic benefits and quality of life during improved glycemic control in patients with type 2 diabetes mellitus: A randomized, controlled, double-blind trial. JAMA 1998; 280:1490-1496.

42. Kato I, Vogelman JH, Dilman V, et al. Effect of supplementation with chromium picolinate on antibody titers to 5-hydroxymethyl uracil. Eur J Epidemiol 1998;14:621-626.

43. Anderson RA. Chromium, glucose intolerance and diabetes. J Am Coll Nutri 1998;17:548-555.

44. Berner TO, Murphy MM, Slesinski R. Determining the safety of chromium tripicolinate for addition to foods as a nutrient supplement. Food Chem Toxicol 2004; 42:1029-1042.

45. Ravina A, Slezak L, Mirsky N, Bryden NA, Anderson RA. Reversal of corticosteroid-induced diabetes mellitus with supplemental chromium. Diabet Med 1999; 16:164-167.

46. Rabinovitz H, Leibovitz A, Madar Z, Gabai G, Habot B. Blood glucose and lipid levels following chromium supplementation in diabetic elderly patients on a rehabilitation program. Gerontologist 1999;40:38.

47. Morris BW, Kouta S, Robinson R, MacNeil S, Heller $\mathrm{S}$. Chromium supplementation improves insulin resistance in patients with type 2 diabetes mellitus. Diabet Med 2000;17:684-686.

48. Lee NA, Reasner CA. Beneficial effect of chromium supplementation on serum triglyceride levels in NIDDM. Diabetes Care 1994;17:1449-1452.

49. Jovanovic L, Gutierrez M, Peterson CM. Chromium supplementation for women with gestational diabetes mellitus. J Trace Elem Exp Med 1999;12:91-97.

50. Ghosh D, Bhattacharya B, Mukherjee B, et al. Role of chromium supplementation in Indians with type 2 diabetes mellitus. J Nutr Biochem 2002;13:690697.
51. Evans GW. Effect of chromium picolinate on insulin controlled parameters in humans. Int J Biosocial Med Res 1989;11:163-180.

52. Cheng N, Zhu X, Shi H, et al. Follow-up survey of people in China with type 2 diabetes mellitus consuming supplemental chromium. J Trace Elem Exp Med 1999;12:55-60.

53. Cefalu WT, Fell-Farrow AD, Stegner J, et al. Effect of chromium picolinate on insulin sensitivity in vivo. J Trace Elem Exp Med 1999;12:71-83.

54. Anderson RA, Bryden NA, Polansky MM. Lack of toxicity of chromium chloride and chromium picolinate in rats. J Am Coll Nutr 1997;16:273-279.

55. Bahadori B, Wallner S, Hacker C, Boes U, Komorowski JR, Wascher TC. Effects of chromium picolinate on insulin levels and glucose control in obese patients with Type I diabetes mellitus. Diabetes 1999;48:A349.

56. Hellerstein MK. Is chromium supplementation effective in managing type II diabetes? Nutr Rev 1998;56: 302-306.

57. Althuis MD, Jordan NE, Ludington EA, Wittes JT. Glucose and insulin responses to dietary chromium supplements: a meta-analysis. Am J Clin Nutr 2002; 76:148-155.

58. Haslacker AR, Copp MJ, Tracy TS. In: Cupp MJ, Tracy TS, eds. Dietary supplements: toxicology and clinical pharmacology. Totowa, NJ: Humana Press, 2003: 41-52.

59. Lukaski HC. Chromium as a supplement. Annu Rev Nutr 1999;19:279-302.

60. Anderson RA, Cheng N, Bryden NA, et al. Elevated intakes of supplemental chromium improve glucose and insulin variables in individuals with type 2 diabetes. Diabetes 1997;46:1786-1791.

61. Hathcock JN, Fomous C. Safety issues for chromium picolinate, chromium, and picolinic acid. Council for Responsible Nutrition 2002. Available at: 〈http:// www.nutrition21.com/Science/CRNCrSafety.doc〉 Accessed December 2004.

62. Greenberg D, Komorowski JR, Loveday K. Rat chromosomes are unharmed by orally administered chromium picolinate. J Am Coll Nutr 1999;18:27.

63. Juturu V, Komorowski JR. Chromium and cardiovascular disease. Presented at the 8th World Congress on Heart Failure, Washington, DC, 2002.

64. Clodfelder BJ, Emamaullee J, Hepburn DD, Chakov NE, Nettles HS, Vincent JB. The trail of chromium (III) in vivo from the blood to the urine: the roles of transferring and chromodulin. J Biol Inorg Chem 2001; 6:608-617.

65. Food and Nutrition Board, Institute of Medicine. Dietary reference intakes for vitamin A, vitamin K, arsenic, boron, chromium, copper, iodine, iron, manganese, molybdenum, nickel, silicon, vanadium, and zinc. National Academy Press, 2002. Available at: 〈http://books.nap.edu/catalog/10026.html?onpi_ newsdoc010901〉.

66. Cefalu WT, Martin J, Wachtel D, Zhang XH, Wang ZQ. Chromium picolinate supplementation increases 
insulin-stimulated akt phosphorylation in vivo in skeletal muscle from subjects with type 2 diabetes. Diabetologia 2003;46:A56.

67. Dakshinamurti K, Cheah-Tan C. Biotin-mediated synthesis of hepatic glucokinase in the rat. Arch Biochem Biophys 1968;127:17-21.

68. Dakshinamurti K, Tarrago-Litvak L, Hong HC. Biotin and glucose metabolism. Can J Biochem 1970;48: 493-500.

69. Rodriguez-Melendez R, Cano S, Mendez ST, Velazquez A. Biotin regulates the genetic expression of holocarboxylase synthetase and mitochondrial carboxylases in rats. J Nutr 2001;131:1909-1913.

70. Komorowski JR, De La Harpe J, Cefalu WT, Zhang XH, Wang ZQ, Greenberg D. JCR-LA-cp rats showed improved lipid profiles in response to diets containing chromium picolinate and biotin. Appetite 2001;36:230.

71. Komorowski JR, Greenberg D, Maki KC, Rosenblatt S. Chromium picolinate with biotin attenuates elevation in blood glucose levels in people with type two diabetes ingesting medium carbohydrate nutritional beverages. J Am Coll Nutr 2001;20:abst 73.

72. Adler AI, Stratton IM, Neil HA, et al. Association of glycaemia with macrovascular and microvascular complications of type 2 diabetes (UKPDS 35): prospective observational study. BMJ 2005;321:405-412.

73. McCarty MF. High-dose biotin, an inducer of glucokinase expression, may synergize with chromium picolinate to enable a definitive nutritional therapy for type II diabetes. Med Hypotheses 1999;52:401-406.

74. Komorowski JR, Juturu V. Chromium and biotin combination improves blood sugar control in people with Type 2 diabetes mellitus. Presented at the 18th IDF Congress, Paris, 2003.

75. Wagner EH, Sandhu N, Newtown KM, McCulloch DK, Ramsey SD, Grothaus LC. Effect of improved glycemic control on health care costs and utilization. JAMA 2001;285:182-189.

76. Juturu V, Komorowski J. Program including chromium picolinate and biotin to reduce blood sugar levels in type 2 diabetes. Obesity Res 2003;11:A106 (abst).

77. Juturu V, Komorowski JR, Greenberg D, Maki KC. Chromium with biotin decreases coronary risk lipids and lipoproteins in people with type 2 diabetes ingesting moderate carbohydrate nutritional beverages. FASEB J 2003;17:A456.1--A886.2(689.1)(abst).

78. Kalman DS. Chromium picolinate and type 2 diabetes. Am J Clin Nutr 2003;78:192, author reply 192-193.

79. Albarracin C, Burcham F, Geohas J, Finch M, Komorowski JR. Effect of chromium picolinate and biotin combination on glycosylated hemoglobin and plasma glucose in subjects with type 2 diabetes mellitus with baseline $\mathrm{HbA} 1 \mathrm{C} \geq 10 \%$. Presented at the American Diabetes Association 65th Scientific Sessions, Chicago, 2005.
80. Albarracin C, Fuqua B, Geohas F, et al. Improvement in glycemic control, lipids and insulin sensitivity with the combination of chromium picolinate and biotin in type 2 diabetes mellitus. Presented at the American Diabetes Association. 65th Scientific Sessions, Chicago, 2005.

81. Juturu A, Finch M, Geohas J, Greenberg D, Komorowski JR. Chromium picolinate and biotin combination reduces coronary risk factors. Aterioscler Thromb Vasc Biol 2004;24:88(abst).

82. Albarracin C, Fuqua B, Geohas J, Finch M, Komorowski JR. Effect of chromium picolinate and biotin combination on coronary risk, lipids and lipoproteins in subjects with non-HDL $-\mathrm{C}(\geq 130 \mathrm{mg} / \mathrm{dL})$ in type 2 diabetes mellitus. Presented at the American Heart Association's ATVB, Washington, DC, 2005.

83. Rimm EB, Guallar E, Giovannucci E, et al. Toenail chromium levels and risks of coronary heart disease among normal and overweight men. Presented at the American Heart Association's 42 ${ }^{\text {nd }}$ Annual Conference on Cardiovascular Disease, Epidemiology and Prevention, Honolulu, 2002.

84. Mertz W. Interaction of chromium with insulin: a progress report. Nutr Rev 1988;56:174-177.

85. Jeejeebhoy KN, Chu RC, Marliss EB, Greenberg GR, Bruce-Robertson MD. Chromium deficiency, glucose intolerance, and neuropathy reversed by chromium supplementation, in a patient receiving long-term total parenteral nutrition. Am J Nutr 1977;130:715-718.

86. Ravina A, Slezak L, Rubal A, Mirsky N. Clinical use of the trace element chromium (III) in the treatment of diabetes mellitus. J Trace Elements Exp Med 1995;8:183-190.

87. Yoshikawa H, Tajiri Y, Sako Y, Hashimoto T, Umeda F, Nawata H. Effects of biotin on glucotoxicity or lipotoxicity in rat pancreatic islets. Metabolism 2002; 51:163-168.

88. Romero-Navarro G, Cabrera-Valladares G, German MS, et al. Biotin regulation of pancreatic glucokinase and insulin in primary cultured rat islets and in biotin-deficient rats. Endocrinology 1999;140: 4595-4600.

89. Furukawa Y. Enhancement of glucose-induced insulin secretion and modification of glucose metabolism by biotin. Nippon Rinsho 1999;57:2261-2269.

Address reprint requests to: David B. Nash, M.D., M.B.A. Department of Health Policy Thomas Jefferson University 1015 Walnut St., Ste 115 Philadelphia, PA 19107

E-mail: david.nash@jefferson.edu 